\title{
创设情境 活化教材 有机结合 促进发展
}

\author{
张丛梅 \\ 吉林省白山市浑江区第二实验小学 \\ D O I:10.32629/jief.v2i1.464
}

[摘 要] 在新课改的挑战下, 体育教学必须改变传统授课模式, 在课堂上真正激发学生的学习兴趣, 从教学的各个环节入情入境进行创新。 本文就从一节课堂教学案例出发, 引出一些对体育教学改革的思考与探索。

[关键词] 成设情境; 活化教材; 有机结合

兴趣是促进小学生自主学习的前提, 只有激发和保持学生的学习兴 趣, 才能使学生积极主动地进行学习, 本文一拟对体育课中如何运用情景 教学来激发学生的学习兴趣, 从而调动和发挥学生学习主动性和创新意识 进行探讨。

所谓的情景教学就是从学生的兴趣出发, 注重启发, 培养学生的学习 兴趣, 激发学生学习兴趣和动机, 调动学生学习积极性, 激励他们好奇心、 求知欲, 培养学生的创新精神。体育教学以往的模式就是教师示范传授, 学生被动学习。而把情景教学融入体育课堂中, 在课上把学生带到特定的 活动环境中, 让学生入情入境, 明理知味, 使学生产生优势性兴奋中心, 从而获得最佳的学习方法, 以提高体育课堂的教学效果, 为此我利用学生 已有教学经验, 创设了以下多种教学情境。

1 创设情境, 激发学生的学习兴趣

巧妙地设置情境是激发学生学习兴趣的有效手段, 如我在上《助跑 几步跨过前面一定的高度》这一课时, 我以带领学生背着书包外出郊游为 主线, 创设情景。首先语言激发: “春天, 一个美丽又带有梦幻般的景色 的季节! 在这个季节里, 大地上百花齐放, 万物复苏。这一切的一切, 都 给人带来了欢乐, 今天来了老师带领同学们去郊游, 取感受这美好的季节 吧!” 然后播放《快乐的节日》这一歌曲, 我和同学们踏这快乐的节奏练 习齐步走。紧接着老师说: “同学们! 我们现在来到了一片青草地, 我们 闻到了泥土花香味, 青草芬芳扑鼻而来! 在这里我们做一下韵律书包操 吧”, 巧妙利用书包操来替代枯燥无味的准备活动。书包操做完了, 让我 们的疲劳已经消失了, 我们还要继续前进吧! 开始慢跑几圈后, 老师说 “春 天在哪里? 小溪告诉我: 春天在冰雪融化的溪水中, 像音乐家弹奏的琵琶, 清脆、优美。春天的小河, 也很美丽。小河在阳光的照耀下, 河水一闪一 闪的, 河里有许多小鱼在嬉戏。我们就来到山谷的小溪前, 我们在这里要 跨过小溪练习”。利用小溪我们做本节课的跨步跳练习, 为主题铺垫, 在 学生的头脑里我们是在春天的意境中。通过创设具体形象的场景, 激发学 生浓厚学习兴趣的教学方法。

1.1 角色进入

在教学中, 凭借生活的形象可以激发学生学习的兴趣, 使学生想象 更丰富, 学生兴趣更浓, 如我在上学习《前滚翻》一课, 我是这样设计的, 导言问: “学生看过电视剧《西游记》吗?孙悟空的翻得跟头翻的厉害吗? 想学吗? 那么本节课老师我就伴做孙悟空, 你们都伴作孙悟空的徒弟, 跟 我一起来学习翻跟头好吗?” 然后把本科的内容以西天取经为情景线索。 这样使学生产生浓厚的兴趣, 从而极大地提高学生学习的积极性和主动 性, 加深对学动作的记忆。

1. 2 音乐的配合

优美和谐的音乐更能把儿童引向活泼、愉快的情绪中去表现自己， 培养个性，提高儿童的鉴赏和创造美的能力。利用抒情优美的旋律，营造 出舒心的情境, 使同学们激情奔放, 心情愉悦, 从身心上得到放松。如我 在上学习《前滚翻》一课, 给每个环节都配上不同的《西游记》音乐。在 准备活动时同学们手持体操棒与老师一起做棍棒操, 再配上《猴哥》的曲 子, 节奏明快, 动作高雅, 舒展大方, 是在音乐伴奏下进行动态造型美的 运动, 同学们感觉好像真是在练习孙悟空的金䈨棒。基本练习时用《敢问 路在何方》的曲子, 让学生学习《前滚翻》动作的同时, 好像是在花果山 上的小猴子在操练, 让同学们过足了戏瘾。游戏时《取经路上》一个前滚
翻再加上一个其他动作的搭配组成的游戏活动。现实带有游戏性的表情动 作配上和谐音乐, 更能把儿童引向活泼、愉快的情绪中去表现自己, 培养 个性, 提高儿童鉴赏和创造没得能力, 有利于克服成人化教学。放松时用 《白龙马》的曲子, 根据骑马套缰绳编排的动作, 让学生把本节课的紧张 充分放松。一整系列的曲子贯穿于整个课堂, 使得学生感至这一课是在《西 游记》情景中度过, 寓教于乐, 使学生在轻松, 悦的情境中进行自主探究, 不知不觉中学到本领。

1.3 创新情境游戏

游戏是小学生喜爱的活动, 它的内容丰富多样, 形式生动活融趣味 性、娱乐性、竞争性、健身性等多功能于一体, 符合儿心特点, 利于它来 激发学生参与运动掌握动作基本技能, 使学享受快乐的同时学到了新知 识。如 “持轻物投准” 教学中, 以打 “飞机” 来作为课件, 当勇敢的 “射 手” 用纸做成敌机挂在架子上, 用沙包当 “炮弹” 让学生分散投准, 打中 越多分数越多。再如在我们北方冬季可以上这一课, 我们可以用雪堆成一 个大雪人, 同学把雪入围在中间, 我们可以做打雪人的游戏, 这样学生就 会自己动脑筋, 怎样用力可以打得准。在教学过程中还可以引导学生自己 编、游戏内容和规则, 并让学生自己去组织积极动脑筋, 激发了学生的创 新意识, 使学生越玩兴趣越高, 思路越宽, 还培养了他们独立工作和社会 适应能力

\section{4 想象情景}

想象是创新的基础, 在创新想象时, 要抓住小学生思维活跃, 想象 丰富, 头脑中常有一些超乎常规的 “奇特” 想象的特点, 激发学生的想象 力, 并渗透到课堂的每一个环节, 启发学生多想新花样, 鼓励与众不同, 做他人所不能, 如在做低年级 “走和跑” “小鸡走” “熊走” “小兔跳水” 等等, 进行集体模仿, 这样鼓舞学生的创新精神, 也提高了学生的创造能力。

2 结论

2.1 情境教学有利于培养学生对体育活动的兴趣和创新能力, 想象能 力, 有利于掌握体育技能, 增进学生深心健康和促进社会适应能力, 是小 学生体育教育的有力手段。

2.2 情境教学能避免体育教学中的 “说教式” 传统方法, 使学生在活 动、锻炼、玩乐中受到潜移默化的教育。

2.3 情境教学能调动学生学习的积极性和主动性, 也有利于课堂教学 任务的完成, 枯燥的教材, 单调的练习变得生动有趣, 学生学得愉快, 练 的高兴。

总之, 开展情境教学, 要针对小学生兴趣广泛, 模仿力强的特点, 有意识地进行, 要熟练掌握教材, 全面构思课的内容, 精心设计课的结构, 具体安排, 尽量让学生成为课堂教学上的主人, 多一些选择, 多一些想象, 多一份自主创新的主动权, 让他们体验到学习的乐趣, 验到创新的满足。

[参考文献]

[1]李雪琴. 数学教学生活化探究 $[J]$.甘肃教育,2019(02):60.

[2] 吴燕楠.灵动的教材 活化的课程一一小学数学主题学习背景下的 秋天课程的实施 [J].数学学习与研究,2018(16):157.

[3]姜慧滋. 基于教材内容 进行整体设计一以《狐假虎威》一课的 教学为例 $[J]$.小学教学参考, 2018(10):80.

作者简介: 张丛梅 (1971- ), 女, 汉族, 山东人, 本科, 研究方 向：小学体育。 